\title{
Review Study: The Effects of Ultrasound-guided Dry Needling on Patients With Myofascial Pain Syndrome
}

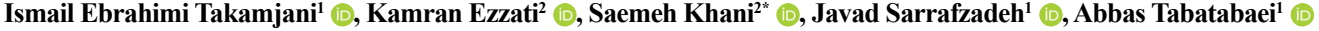

1. Department of Physiotherapy, School of Rehabilitation Sciences, Iran University of Medical Sciences, Tehran, Iran.

2. Neuroscience Research Center, Faculty of Medicine, Poorsina Hospital, Guilan University of Medical Sciences, Rasht, Iran.

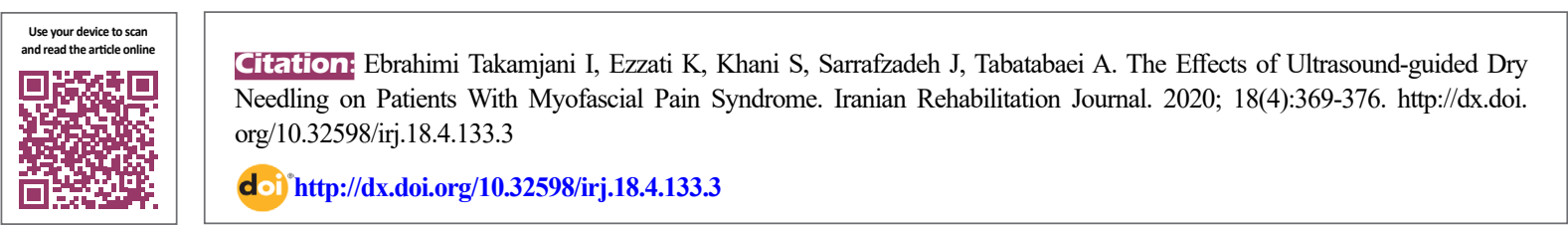

(c) (i) (\$)

Article info:

Received: 19 Jun 2020

Accepted: 10 Nov 2020

Available Online: 01 Dec 2020

\section{Keywords:}

Ultrasound-guided,

Ultrasonography, Dry needling, Trigger points, Musculoskeletal pain, Myofascial pain syndrome

\section{ABSTRACT}

Objectives: Dry Needling (DN) is a novel and effective intervention for patients with Myofascial Pain Syndrome (MPS). Some characteristics, such as needle penetration depth, needle insertion into the target muscle, and trigger points must be identified in this intervention. The Ultrasound (US)-guided DN is a technique that involves needle insertion at the site of injury and the simulation of tissue injury and inflammation under US guidance; it indicates the needle insertion site to ensure that it does not penetrate the adjacent tissues. The current study aimed to review previous studies regarding the effects of US-guided DN on MPS.

Methods: A search was performed in PubMed, Scopus, Cochrane, Google Scholar, Springer, and Science Direct databases to retrieve studies published from 2010 to March 2020. We included investigations regarding the effects of US-guided DN on the treatment of MPS. The following keywords and MeSH terms were used in the search process: "ultrasound-guided, musculoskeletal ultrasonography, myofascial pain syndrome, trigger points, and dry needling."

Results: A total of 47 relevant articles were retrieved. However, based on the inclusion and exclusion criteria of the review, 11 articles were finally selected. All studies reported significant pain relief following the use of US-guided DN in patients with MPS.

Discussion: Considering the precise visualization of the site of muscle involvement, precise needle insertion, and reduction of the risk of further injury in US-guided DN may be a useful approach for MPS management in short-term and long-term studies. 


\section{Highlights}

- US-guided DN may be an effective alternative intervention for patients with MPS, especially those with pain in deep structures.

- The safety of DN, the visualization of trigger points and local twitch response, as well as the insertion of the needle tip into the trigger points of deep muscles, are the main reasons for applying US-guided DN in patients with MPS.

- There is a need for further clinical trials with long-term follow-ups and comparative groups to apply US-guided DN as a common intervention for patients with MPS.

\section{Plain Language Summary}

MPS is a common cause of musculoskeletal disorders. There are many interventions to decrease pain and stiffness in patients with MPS. US-guided DN, in which a needle is inserted under US guidance, can be used as a novel method for treating these patients. The results of this review suggested that US-guided DN may improve therapeutic outcomes in patients with MPS.

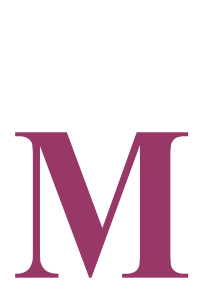

\section{Introduction}

usculoskeletal pain affects up to $86 \%$ of the total population and may be acute or chronic. Approximately $95 \%$ of patients with chronic pain encounter Myofascial Pain Syndrome (MPS), which affects millions of individuals. It also imposes a heavy financial burden on the affected individual and society $[1,2]$. Approximately $54 \%$ of females and $45 \%$ of males are affected by MPS, especially due to a sedentary lifestyle and low physical activity [3]. Evidence suggests that MPS is more prevalent in the age group of 27-50 years. MPS has been studied for more than a century; however, its diagnostic, clinical, and therapeutic aspects remain unclear [2, 3].

MPS is a common, non-articular, and musculoskeletal disorder, characterized by myofascial trigger points [4]. MPS symptoms include diffuse pain, Local Twitch Response (LTR) to pressure, decreased Range of Motion (ROM), and autonomic nervous system-induced symptoms $[2,4]$. Trigger points include hyperirritable spots along the taut bands of muscle fibers; they become painful upon pressure or stretching and can spread with a specific pattern $[3,4]$. Evidence suggests that these trigger points may be either active or latent. Active trigger points, as the primary cause of MPS, are spontaneous. Consequently, they cause familiar symptoms in patients on palpation $[2,3]$. In contrast, latent trigger points do not elicit spontaneous or familiar pain on palpation. The formation of trigger points is multifactorial, depending on factors, such as inappropriate posture, poor biomechanics, overuse, direct trauma, and stress [5].
Aguilar et al. reported that $60 \%$ of costs related to physical treatment for chronic pain cannot be justified [6] Therefore, evidence-based interventions are emphasized in pain management, especially MPS [7]. Several therapeutic approaches are implemented to treat MPS. Deep Dry Needling (DN) has recently attracted the attention of medical researchers [8]. DN is a frequent therapeutic technique, in which a solid, filiform, and stainless steel needle is inserted through the skin [7]. Inserting needles into the target soft tissues causes mechanical hyperstimulation and manipulation [9]. Bruises, bleeding, and soreness are the three most frequent adverse effects of DN. Besides, these adverse effects are associated with DN techniques, like the number of needle insertions into the trigger points [10].

There are controversies regarding the efficacy, safe application, neuromuscular complications, and needle insertion effects (e.g. LTR) of DN. Moreover, the evaluation of treatment outcomes is a major concern following DN [7-11]. In this regard, Baraja-Vegas et al. indicated that DN may elicit intramuscular edema and alternations in the contractile properties of muscles [11]. The need for information, such as the needle penetration depth, needle insertion into the target muscle and trigger points, as well as the prevention of needle penetration into the adjacent structures (e.g. nerves) has led researchers to employ diagnostic Ultrasound (US) along with DN [7, 9].

US is an essential tool in diagnosing and treating injuries to soft tissues, including the muscles, tendons, and nerves $[2,12]$. B-mode and linear probe US interventions are used to monitor the condition of musculoskel- 
etal tissues [13]. US can visualize various structures of the musculoskeletal tissue with particular characteristics. For instance, the muscle and the surrounding fascia are observed to be hypoechoic in US, whereas the skin is a hyperechoic structure $[12,13]$. US-guided interventions include surgical and conservative treatment approaches. The US-guided DN is a technique, involving needle insertion at the site of injury, the simulation of tissue injury, and inflammation under US guidance. Such a process indicates the needle insertion site to ensure that it does not penetrate the adjacent tissue [13]. Other treatment methods, including injection, cryotherapy, prolotherapy, and electrocoagulation are also US-guided interventions [13]. Thus, the current study aimed to review previous research regarding the effects of US-guided DN on MPS.

\section{Methods}

A search was conducted in PubMed, Scopus, Google Scholar, CINAHL, Ovid, Cochrane, ProQuest, and Science Direct databases to retrieve articles published from 2010 to March 2020. We included data regarding the effects of US-guided DN on the treatment of MPS. The following keywords and MeSH terms were used in the present search: "Ultrasound-guided, musculoskeletal ultrasonography, dry needling, trigger points, musculoskeletal pain, and myofascial pain syndrome". A total of 47 relevant articles were retrieved by searching the abovementioned databases.

The inclusion criteria of the present review were as follows: retrospective and prospective, experimental, quasiexperimental, and observational studies; English articles on the effects of US-guided DN on MPS, and relevant articles published from 2010 to March 2020. Based on the inclusion and exclusion criteria (using US-guided DN as the main inclusion criterion), a total of 11 articles were finally reviewed [14-24]. Three of these studies were randomized clinical trials, comparing US-guided DN with other treatment methods $[15,18,22]$; 5 were case reports and case-series [14, 17, 19, 21, 24]; two were retrospective analyses of the effect of US-guided DN on the treatment of MPS [16, 23], and one was a single-group, pretest, post-test study [20].

All studies on the effect of US-guided DN were reviewed, regardless of the trigger points. The selected articles defined and evaluated the outcomes, using the following tools: the Visual Analog Scale (VAS) and the Numeric Pain Rating Scale (NPRS) for pain analysis [25, 26]; a goniometer for ROM [27]; as well as the Neck Disability Index (NDI) and Disabilities of the Arm, Shoulder, and Hand (DASH) questionnaire for disability [28, 29].
Two reviewers (KE \& SK) independently evaluated the titles and abstracts of studies on US-guided DN for patients with MPS. Besides, the reviewers independently screened the full-text articles. Moreover, the two raters evaluated the methodological quality of the selected articles.

There exist no standard criteria to evaluate the methodological quality of single-case studies [30]. Tate et al. developed a Single-Case Experimental Design (SCED) scale for this purpose. The SCED is an 11-item rating scale, with 10 items on the methodological quality and statistical analysis [30]. Moreover, the quality of Randomized Controlled Trials (RCTs) was assessed, using the 11-point Physiotherapy Evidence Database (PEDro) scale, i.e. a reliable and valid instrument. A PEDro score of $\geq 7$ represents a high methodological quality, whereas a PEDro score of $\leq 5$ represents a low methodological quality [31].

\section{Results}

Initially, we retrieved 47 relevant articles in this review research. However, 18 studies were excluded based on the title and abstract. The full-texts of 29 remaining articles were screened. Furthermore, 18 articles were excluded due to inappropriate study designs, non-English writing, and reporting other diseases rather than myofascial pain. Finally, 11 articles were included for further analysis and methodological quality assessment (Table 1). All studies were of moderate [24] to high [14, 15, 17-19, 21, 22] quality (PEDro score: $\geq 5$ ), except for 3 retrospective investigations $[16,20,23]$. All studies were of moderate to high quality (PEDro score: $\geq 5$ ). Approximately $91 \%$ of the included articles $(n=10)$ reported the positive effects of US-guided DN on the outcome measures, like pain. Almost all studies reported pain reduction and improvement of outcomes following the use of US-guided DN. In this regard, Zheng et al. compared US-guided DN with US-guided mini scalpel needle release technique in patients with chronic neck pain. The relevant results indicated the efficacy of both treatments and the superiority of mini scalpel needle release over DN [15]. Moreover, the disability index was assessed in 44 patients with complex regional pain syndrome. The related results demonstrated that US-guided DN significantly improved outcomes at 15 and 45 days after treatment [16]. Fusco et al. explored the effects of US-guided DN on three patients with piriformis syndrome. Accordingly, they reported positive outcomes one day after the intervention and in the 6-month follow-up [21].

Vas and Pai reported improvements in the symptoms after one session of US-guided plane block and 3 sessions of US-guided DN. Furthermore, significant pain 
Table 1. The general information and methodological quality of the included studies

\begin{tabular}{|c|c|c|c|c|c|c|}
\hline Authors (y) & $\begin{array}{c}\text { Disease, } \\
\text { Sample Size }\end{array}$ & $\begin{array}{l}\text { Type of Ar- } \\
\text { ticle (Main } \\
\text { Inclusion } \\
\text { Criteria) }\end{array}$ & Methods & Measurement & Follow-up & Results \\
\hline $\begin{array}{l}\text { Bubnov et al. } \\
(2013)[14] \\
\text { SCED: } 7\end{array}$ & $\begin{array}{c}\text { Trigger points, } \\
133\end{array}$ & Case series & $\begin{array}{c}\text { Group A: US-guided } \\
\text { DN } \\
\text { Group B: DN }\end{array}$ & Pain (VAS) & $\begin{array}{l}24 \text { hours after } \\
\text { the interven- } \\
\text { tion }\end{array}$ & $\begin{array}{l}\text { Group } A(M D=6.1) \\
\text { Group } B(M D=4.5)\end{array}$ \\
\hline $\begin{array}{l}\text { Zheng et al. } \\
\text { (2014) [15] } \\
\text { PEDro score: } 9\end{array}$ & $\begin{array}{l}\text { Chronic neck } \\
\text { pain, } 60\end{array}$ & $\mathrm{RCT}$ & $\begin{array}{c}\text { Group A: US-guided } \\
\text { miniscalpel DN } \\
\text { Group B: US-guided } \\
\text { DN }\end{array}$ & $\begin{array}{c}\text { Pain } \\
\text { (VAS), neck dis- } \\
\text { ability, and SF-36 } \\
\text { health survey }\end{array}$ & $\begin{array}{l}3 \text { and } 6 \text { months } \\
\text { after the inter- } \\
\text { vention }\end{array}$ & $\begin{array}{l}\text { the superiority of } \\
\text { US-guided mini } \\
\text { scalpel DN over } \\
\text { US-guided DN }\end{array}$ \\
\hline $\begin{array}{l}\text { Vas et al. } \\
(2016)[16]\end{array}$ & $\begin{array}{l}\text { Complex } \\
\text { regional pain } \\
\text { syndrome } \\
\text { type } 1,44\end{array}$ & $\begin{array}{l}\text { Retrospec- } \\
\text { tive (pre-test, } \\
\text { post-test } \\
\text { design) }\end{array}$ & $\begin{array}{c}\text { Treatment with } \\
\text { medications plus US- } \\
\text { guided DN for neck } \\
\text { and upper extremity } \\
\text { muscles }\end{array}$ & $\begin{array}{l}\text { Pain (VAS), ROM, } \\
\text { and DASH score }\end{array}$ & $\begin{array}{l}15 \text { and } 45 \\
\text { days after the } \\
\text { intervention }\end{array}$ & $\begin{array}{l}\text { The lack of pain, } \\
\text { pain-free full ROM, } \\
\text { and improved } \\
\text { DASH scores due } \\
\text { to treatment }\end{array}$ \\
\hline $\begin{array}{l}\text { Vas et al. } \\
(2016)[17] \\
\text { SCED score: } 6\end{array}$ & $\begin{array}{c}\text { Pancreatic } \\
\text { cancer pain, } 5\end{array}$ & Case series & $\begin{array}{l}\text { The US-guided DN of } \\
\text { abdominal and back } \\
\text { muscles plus neuro- } \\
\text { lytic coeliac plexus } \\
\text { block or splanchnic } \\
\text { nerve radiofrequen- } \\
\text { cy ablation }\end{array}$ & $\begin{array}{l}\text { Pain } \\
\text { (NRS) }\end{array}$ & $\begin{array}{c}3 \text { and } 15 \text { days } \\
\text { after the inter- } \\
\text { vention }\end{array}$ & $\begin{array}{l}\text { Significant pain } \\
\text { relief }\end{array}$ \\
\hline $\begin{array}{c}\text { Sánchez-Mila } \\
\text { et al. (2018) } \\
\text { [18] } \\
\text { PEDro score: } 7\end{array}$ & Stroke, 26 & $\mathrm{RCT}$ & $\begin{array}{c}\text { Group A: Bobath } \\
\text { only } \\
\text { Group B: Bobath } \\
\text { plus DN }\end{array}$ & $\begin{array}{c}\text { Modified } \\
\text { Ashworth Scale, } \\
\text { Fugl-Meyer motor } \\
\text { scale, and com- } \\
\text { puterized dynamic } \\
\text { posturography }\end{array}$ & $\begin{array}{l}10 \text { minutes } \\
\text { after treatment }\end{array}$ & $\begin{array}{l}\text { Improved spastic- } \\
\text { ity, function, and } \\
\text { postural control }\end{array}$ \\
\hline $\begin{array}{l}\text { Pai and Vas } \\
\text { (2018) [19] } \\
\text { SCED score: } 7\end{array}$ & $\begin{array}{l}\text { Complex } \\
\text { regional pain } \\
\text { syndrome } \\
\text { type } 1,1\end{array}$ & Case study & $\begin{array}{l}\text { US-guided DN plus } \\
\text { medications and stel- } \\
\text { late ganglion block }\end{array}$ & $\begin{array}{l}\text { DASH score, pain- } \\
\text { DETECT question- } \\
\text { naire, and patient } \\
\text { health question- } \\
\text { naire-9 }\end{array}$ & 1 year & $\begin{array}{c}\text { Functional im- } \\
\text { provement }\end{array}$ \\
\hline $\begin{array}{c}\text { Bubnov and } \\
\text { Kalika (2018) } \\
\text { [20] }\end{array}$ & $\begin{array}{l}\text { Low back pain, } \\
23\end{array}$ & $\begin{array}{l}\text { Pre-test, } \\
\text { post-test }\end{array}$ & US-guided DN & $\begin{array}{c}\text { Pain scale } \\
\text { (VAS) and Leeds } \\
\text { Assessment of } \\
\text { Neuropathic Symp- } \\
\text { toms and Signs }\end{array}$ & $\begin{array}{l}\text { Before, imme- } \\
\text { diately after, } 24 \\
\text { hours after, and } \\
7 \text { days after the } \\
\text { intervention }\end{array}$ & $\begin{array}{l}\text { Improved pain, } \\
\text { nerve structure, } \\
\text { motility, and con- } \\
\text { tractility }\end{array}$ \\
\hline $\begin{array}{l}\text { Fusco et al. } \\
(2018)[21] \\
\text { SCED score: } 6\end{array}$ & $\begin{array}{c}\text { Piriformis } \\
\text { syndrome, } 3\end{array}$ & Case series & $\begin{array}{c}\text { US-guided DN for the } \\
\text { piriformis and gluteal } \\
\text { muscles }\end{array}$ & Pain (NRS) & $\begin{array}{c}6 \text { months after } \\
\text { treatment }\end{array}$ & $\begin{array}{l}\text { Complete pain } \\
\text { relief }\end{array}$ \\
\hline $\begin{array}{l}\text { Tabatabaei et } \\
\text { al. (2019) [22] } \\
\text { PEDro score: } 8\end{array}$ & $\begin{array}{c}\text { Piriformis syn- } \\
\text { drome, } 32\end{array}$ & $\mathrm{RCT}$ & $\begin{array}{l}\text { Group A: US-guided } \\
\text { DN plus home rec- } \\
\text { ommendations } \\
\text { Group B: Home } \\
\text { recommendations }\end{array}$ & $\begin{array}{l}\text { Pain (VAS), Oswes- } \\
\text { try disability index, } \\
\text { pressure pain } \\
\text { threshold, and hip } \\
\text { joint ROM }\end{array}$ & $\begin{array}{c}24 \text { hours, } 72 \\
\text { hours, and } 1 \\
\text { week after the } \\
\text { intervention }\end{array}$ & $\begin{array}{c}\text { The superiority of } \\
\text { the intervention } \\
\text { with various effect } \\
\text { sizes }\end{array}$ \\
\hline $\begin{array}{l}\text { Vas and Pai } \\
(2019)[23]\end{array}$ & $\begin{array}{l}\text { Postmastec- } \\
\text { tomy pain } \\
\text { syndrome, } 20\end{array}$ & $\begin{array}{l}\text { Retrospec- } \\
\text { tive (pre-test, } \\
\text { post-test) }\end{array}$ & $\begin{array}{c}\text { Group A: US-guided } \\
\text { DN plus neural inter- } \\
\text { ventions } \\
\text { Group B: US-guided } \\
\text { DN }\end{array}$ & $\begin{array}{c}\text { DASH score, } \\
\text { painDETECT score, } \\
\text { Patient Health } \\
\text { Questionnaire-9, } \\
\text { and opioid use } \\
\text { scale }\end{array}$ & - & $\begin{array}{l}\text { Reduction of pain, } \\
\text { disability, and } \\
\text { opioid use }\end{array}$ \\
\hline $\begin{array}{l}\text { Kurosawa et } \\
\text { al. (2019) [24] } \\
\text { SCED score: } 5\end{array}$ & $\begin{array}{l}\text { Shoulder } \\
\text { pain, } 1\end{array}$ & Case study & US-guided DN & $\begin{array}{c}\text { Pain (NRS) and } \\
\text { ROM }\end{array}$ & $\begin{array}{l}2 \text { weeks after } \\
\text { the interven- } \\
\text { tion }\end{array}$ & $\begin{array}{l}\text { Pain reduction and } \\
\text { improved ROM }\end{array}$ \\
\hline
\end{tabular}

SCED: Single-Case Experimental Design; US: Ultrasound; DN: Dry Needling; VAS: Visual Analog Scale; MD: Mean Difference; RCT: Randomized Controlled Trial; DASH: Disabilities of the Arm, Shoulder, and Hand Index; NRS: Numerical Rating Scale; ROM: Range of Motion. 
Table 2. The purposes and assessment time of US-guided DN in patients with MPS ( $n=11)$

\begin{tabular}{cr}
\hline Goals & US-guided DN \\
\hline Guidance (100\%) & Immediately after the intervention (45\%) \\
LTR (54\%) & Short-term follow-up (54\%) \\
Trigger point visualization (36\%) & Long-term follow-up (27\%) \\
Visualization of deep structures (100\%) & - \\
\hline
\end{tabular}

US: Ultrasound; DN: Dry Needling; LTR: Local Twitch Response.

Iranian Rehabilitation Journal

relief was observed at a 4-month follow-up assessment [23]. Tabatabaei et al. investigated the effects of USguided DN on piriformis syndrome. Thirty-two patients with piriformis syndrome were divided into two groups. One group received US-guided DN and home recommendations, while the other group only received home recommendations. The explored patients were evaluated at 24 and 72 hours, as well as one week after the intervention concerning pain, hip external and internal rotations, disability, and pressure pain tolerance. The results of the study by Tabatabaei et al. signified that the group receiving US-guided DN presented significantly better outcomes than the controls in terms of pain relief and internal ROM with a great effect size. However, there was no significant difference between the study groups regarding the increased pressure pain tolerance (with a moderate effect size) and disability (with a small effect size) [22]. The details of the reviewed articles on using US-guided DN, including the author's name, sample size, article type, the number of interventions, study duration, studied variables, and relevant results are listed in Table 1.

According to Table 2, the main applications of USguided DN included guidance $(100 \%)$, the evaluation of deep structures $(100 \%)$, LTR visualization (54\%) $[14,16,18,19,21,22]$, and trigger point visualization $(36 \%)$ [14, 20, 24], respectively. Additionally, nearly $54 \%$ of the included studies on US-guided DN evaluated the outcomes in short-term follow-ups [15-20, 22-24]; whereas long-term follow-ups were only performed in $27 \%$ of the studies $[15,21]$ (Table 2 ).

Moreover, in $63 \%$ of the reviewed studies, the number of US-guided DN sessions was less than 3 [14-18, 20, 22]. Only about $10 \%$ of the studies reported the adverse effects of US-guided DN [15]. Eventually, the validity and repeatability of the methods of the included studies were not reported.

\section{Discussion}

According to the present research results, US-guided DN improves therapeutic outcomes, like pain in patients with MPS [14-24]. DN is an invasive method, i.e. usually implemented for patients with MPS [32]. In Deep DN, the needles may penetrate $>4 \mathrm{~cm}$ into tissues [3]. Thus, targeting and visualizing tissue using US may influence the patient's treatment outcomes and complications after DN [14]. A review on the effects of DN on chronic low back pain concluded that the clinical superiority of DN and its follow-up efficacy were unclear [33]. Besides, the International Conference on Invasive Physical Therapy (ICIPT) recommended using US during needling. The safety considerations, visualizing deep tissues and LTR, and recording changes and outcomes were mentioned as the main reasons for applying US [9]. However, the main purpose of US-guided DN is to guide fine needles into deep muscles [14-24].

In a previous study, the superiority of US-guided mini scalpel needling over US-guided DN was attributed to differences in needle penetration into the target and the US-guided needling procedure [15]. In US-guided mini scalpel needling, the needle was inserted into the extensor neck muscle, and the trigger point was destructed. However, in US-guided DN, the needle was inserted into the tight neck extensor muscle and not exactly the trigger point [15]; this difference can be a major reason for the superiority of US-guided Miniscalpel needling over USguided DN [15]. LTR eliciting under US guidance is another essential feature of this method [14, 16, 18-20, 22].

Significant pain relief was reported in another study that used US-guided DN for treating patients with piriformis syndrome, compared to the controls [22]. However, the used technique provided a small effect size for the disability index, compared to the control group. Such data could be attributed to the short-term follow-up, as the patients required adequate time to improve their 
abilities following therapy [22]. Regarding the hip ROM index, the piriformis muscle is a short external rotator muscle of the hip joint; therefore, pain relief, induced by US-guided DN, improved the muscle stiffness symptoms and allowed further internal hip rotation. However, no significant superiority over the control group was observed respecting external hip rotation, as a muscle function. Regarding the pressure pain tolerance, due to the micro-trauma caused by DN in the muscle, the pressure pain threshold further increased in the intervention group in less than a week following US-guided DN, with moderate effect size, compared to the controls [22].

There are some controversies regarding the US visualization of trigger points in MPS patients [12]. The least common application of US-guided DN is the visualization of trigger points [14, 20, 24]. Previous studies revealed that US fails to identify the exact echogenicity changes [12]. The mechanism of action of DN in pain relief among patients with MPS remains undiscovered [9]. However, therapists can employ needles with an appropriate length to minimize the micro-trauma caused by muscle stimulation; this is due to the effectiveness of this therapeutic technique, the inadequate availability of all muscles, the risk of damage to vessels entering the muscles and the surrounding nerves, and the odds of monitoring muscles through US [10, 12].

US technique allows us to observe LTR in deep muscles (indicating precise needle insertion into the trigger point of the muscle); thus, applying diagnostic US alongside DN, as a therapeutic modality, can significantly help patients [4, 9, 14-24]. US-guided DN seems to be able to increase pain relief and decrease the number of treatment sessions in MPS patients [14]. According to the present research findings, US-guided DN may be a safe and suitable alternative for the conventional interventions of MPS [21].

The results of the reviewed studies suggested considerable improvements in pain after US-guided DN; however, there were some limitations in these studies. First, in some studies, needle insertion was performed in different muscles $[14,16,19]$. Second, US was used for various purposes, such as needle guidance, LTR visualization, and the visualization of trigger points or deep structures [14-24]. Third, the repeatability of the methods was suspected in numerous studies [14-24]. Four, almost all studies evaluated the immediate or short-term effects of US-guided DN [16, 17]. Finally, the cost of US equipment and educational courses, besides the feasibility of protocols, should be considered in future studies [14].

\section{Conclusion}

Based on the data reported in the literature, US-guided DN may help treat patients with MPS. However, further RCTs with longer follow-up courses may provide more conclusive results.

\section{Ethical Considerations}

\section{Compliance with ethical guidelines}

All ethical principles were considered in this article.

Funding

This research did not receive any specific grant from funding agencies in the public, commercial, or not-forprofit sectors.

\section{Authors' contributions}

Conceptualization: Ismail Ebrahimi Takamjani, Kamran Ezzati, Saemeh Khani, Javad Sarrafzadeh; Methodology: Ismail Ebrahimi Takamjani, Saemeh Khani, Javad Sarrafzadeh, Abbas Tabatabaiee; Software: Saemeh Khani, Kamran Ezzati, Validation: Ismail Ebrahimi Takamjani, Javad Sarrafzadeh, Kamran Ezzati; Formal analysis: Kamran Ezzati, Abbas Tabatabaiee, Saemeh Khani; Investigation: Ismail Ebrahimi Takamjani, Kamran Ezzati, Saemeh Khani, Javad Sarrafzadeh, Abbas Tabatabaiee; Data curation: Kamran Ezzati, Saemeh Khani, Abbas Tabatabaiee; Writing - original draft preparation: Saemeh Khani, Kamran Ezzati, Abbas Tabatabaiee, Ismail Ebrahimi Takamjani; Writing - review \& editing: Ismail Ebrahimi Takamjani, Kamran Ezzati, Saemeh Khani, Javad Sarrafzadeh, Abbas Tabatabaiee; Visualization: Javad Sarrafzadeh, Ismail Ebrahimi Takamjani; Supervision: Ismail Ebrahimi Takamjani.

\section{Conflict of interest}

The authors declared no conflicts of interest.

\section{Acknowledgments}

The authors would like to thank the Iran University of Medical Sciences for supporting this research. 


\section{References}

[1] Segura-Pérez M, Hernández-Criado MT, Calvo-Lobo C, VegaPiris L, Fernández-Martín R, Rodríguez-Sanz D. A multimodal approach for myofascial pain syndrome: A prospective study. Journal of Manipulative and Physiological Therapeutics. 2017; 40(6):397-403. [DOI:10.1016/j.jmpt.2017.06.001] [PMID]

[2] Salavati M, Akhbari B, Takamjani IE, Ezzati K, Haghighatkhah $\mathrm{H}$. Reliability of the upper trapezius muscle and fascia thickness and strain ratio measures by ultrasonography and sonoelastography in participants with myofascial pain syndrome. Journal of Chiropractic Medicine. 2017; 16(4):316-23. [DOI:10.1016/j. jcm.2017.06.003] [PMID] [PMCID]

[3] DommerholtJ, de las Penas CF. Trigger point dry needlinge-book: An evidence and clinical-based approach. $2^{\text {th }}$ ed. Netherlands: Elsevier Health Sciences; 2018. https:// www.elsevier.com/books/ trigger-point-dry-needling/dommerholt/978-0-7020-7416-5

[4] Chiarotto A, Clijsen R, Fernandez-De-Las-Penas C, Barbero M. Prevalence of myofascial trigger points in spinal disorders: A systematic review and meta-analysis. Archives of Physical Medicine and Rehabilitation. 2016; 97(2):316-37. [DOI:10.1016/j. apmr.2015.09.021] [PMID]

[5] Lluch E, Nijs J, De Kooning M, Van Dyck D, Vanderstraeten $\mathrm{R}$, Struyf F, et al. Prevalence, incidence, localization, and pathophysiology of myofascial trigger points in patients with spinal pain: A systematic literature review. Journal of Manipulative and Physiological Therapeutics. 2015; 38(8):587-600. [DOI:10.1016/j. jmpt.2015.08.004] [PMID]

[6] Serrano-Aguilar P, Kovacs FM, Cabrera-Hernández JM, RamosGoñi JM, García-Pérez L. Avoidable costs of physical treatments for chronic back, neck and shoulder pain within the Spanish national health service: A cross-sectional study. BMC Musculoskeletal Disorders. 2011; 12:287. [DOI:10.1186/1471-2474-12-287] [PMID] [PMCID]

[7] Fernández-de-Las-Peñas C, Nijs J. Trigger point dry needling for the treatment of myofascial pain syndrome: Current perspectives within a pain neuroscience paradigm. Journal of Pain Research. 2019; 12:1899-911. [DOI:10.2147/JPR.S154728] [PMID] [PMCID]

[8] Hakim IK, Takamjani IE, Sarrafzadeh J, Ezzati K, Bagheri R. The effect of dry needling on the active trigger point of upper trapezius muscle: Eliciting local twitch response on long-term clinical outcomes. Journal of Back and Musculoskeletal Rehabilitation. 2019; 32(5):717-24. [DOI:10.3233/BMR-181286] [PMID]

[9] Secorro N, Guerra R, Labraca X, Lari M, Pecos D, Torres B, et al. Clinical criteria for the application of dry needling in myofascial pain syndrome: An expert consensus document and a crosssectional study among physical therapists. Revista Fisioterapia Invasiva/Journal of Invasive Techniques in Physical Therapy. 2019; 2(2):50-4. [DOI:10.1055/s-0039-3402788]

[10] Martín-Pintado-Zugasti A, Fernández-Carnero J, León-Hernández JV, Calvo-Lobo C, Beltran-Alacreu H, Alguacil-Diego I, et al. Postneedling soreness and tenderness after different dosages of dry needling of an active myofascial trigger point in patients with neck pain: A randomized controlled trial. PM \& R. 2018; 10(12):1311-20. [DOI:10.1016/j.pmrj.2018.05.015] [PMID]

[11] Baraja-Vegas L, Martín-Rodríguez S, Piqueras-Sanchiz F, Faundez-Aguilera J, Bautista IJ, Barrios C, et al. Localization of muscle edema and changes on muscle contractility after dry needling of latent trigger points in the gastrocnemius muscle. Pain Medicine. 2019; 20(7):1387-94. [DOI:10.1093/pm/pny306] [PMID]
[12] Kumbhare D, Singh D, Rathbone HA, Gunn M, GrosmanRimon L, Vadasz B, et al. Ultrasound-guided interventional procedures: Myofascial trigger points with structured literature review. Regional Anesthesia \& Pain Medicine. 2017; 42(3):407-12. [DOI:10.1097/AAP.0000000000000572] [PMID]

[13] Davidson J, Jayaraman S. Guided interventions in musculoskeletal ultrasound: What's the evidence? Clinical Radiology. 2011; 66(2):140-52. [DOI:10.1016/j.crad.2010.09.006] [PMID]

[14] Bubnov RV, Wang J. Clinical comparative study for ultrasoundguided trigger-point needling for myofascial pain. Medical Acupuncture. 2013; 25(6):437-43. [DOI:10.1089/acu.2013.0973]

[15] Zheng Y, Shi D, Wu X, Gu M, Ai Z, Tang K, et al. Ultrasoundguided miniscalpel-needle release versus dry needling for chronic neck pain: A randomized controlled trial. Evidence-Based Complementary and Alternative Medicine. 2014; 2014:235817. [DOI:10.1155/2014/235817] [PMID] [PMCID]

[16] Vas LC, Pai R, Pattnaik M. Musculoskeletal ultrasonography in CRPS: Assessment of muscles before and after motor function recovery with dry needling as the sole treatment. Pain Physician. 2016; 19(1):E163-79. [DOI:10.1093/pm/pnx124] [PMID]

[17] Vas L, Phanse S, Pai R. A new perspective of neuromyopathy to explain intractable pancreatic cancer pains; dry needling as an effective adjunct to neurolytic blocks. Indian Journal of Palliative Care. 2016; 22(1):85-93. [DOI:10.4103/0973-1075.173957] [PMID] [PMCID]

[18] Sánchez-Mila Z, Salom-Moreno J, Fernández-de-las-Peñas C. Effects of dry needling on post-stroke spasticity, motor function and stability limits: A randomised clinical trial. Acupuncture in Medicine. 2018; 36(6):358-66. [DOI:10.1136/acupmed-2017-011568] [PMID]

[19] Pai RS, Vas L. Ultrasound-guided intra-articular injection of the radio-ulnar and radio-humeral joints and ultrasound-guided dry needling of the affected limb muscles to relieve fixed pronation deformity and myofascial issues around the shoulder, in a case of complex regional pain syndrome type 1. Pain Practice. 2018, 18(2):273-82. [DOI:10.1111/papr.12596] [PMID]

[20] Bubnov R, Kalika L, Spivak M. Dry needling of myofascial trigger points under ultrasound guidance reduce the symptoms of peripheral neuropathy. EFIC Congress 2019 - Pain in Europe XI. September 2019. Valencia, Spain https:/ / www.researchgate.net/ profile/Rostyslav_Bubnov/publication/336216751_

[21] Fusco P, Di Carlo S, Scimia P, Degan G, Petrucci E, Marinangeli F. Ultrasound-guided dry needling treatment of myofascial trigger points for piriformis syndrome management: A case series. Journal of Chiropractic Medicine. 2018; 17(3):198-200. [DOI:10.1016/j. jcm.2018.04.002] [PMID] [PMCID]

[22] Tabatabaiee A, Takamjani IE, Sarrafzadeh J, Salehi R, Ahmadi M. Ultrasound-guided dry needling decreases pain in patients with piriformis syndrome. Muscle \& Nerve. 2019; 60(5):558-65. [DOI:10.1002/mus.26671] [PMID]

[23] Vas L, Pai R. Ultrasound-guided dry needling as a treatment for postmastectomy pain syndrome-A case series of twenty patients. Indian Journal of Palliative Care. 2019; 25(1):93-102. [DOI:10.4103/IJPC.IJPC_24_18]

[24] Kurosawa A, Kobayashi T, Namiki H. Ultrasound-guided dry needling for abnormal fascia between the deltoid muscle and the supraspinatus tendon. Pain Medicine. 2020; 21(4):863-4. [DOI:10.1093/pm/pnz321] [PMID] 
[25] Cline ME, Herman J, Shaw ER, Morton RD. Standardization of the visual analogue scale. Nursing Research. 1992; 41(6):378-80. [DOI:10.1097/00006199-199211000-00013]

[26] Clark ME, Gironda RJ, Young RW. Development and validation of the pain outcomes questionnaire-VA. Journal of Rehabilitation Research and Development. 2003; 40(5):381-95. [DOI:10.1682/JRRD.2003.09.0381] [PMID]

[27] Tousignant M, de Bellefeuille L, O'Donoughue S, Grahovac S. Criterion validity of the cervical range of motion (CROM) goniometer for cervical flexion and extension. Spine. 2000; 25(3):324-30. [DOI:10.1097/00007632-200002010-00011] [PMID]

[28] En MCC, Clair DA, Edmondston SJ. Validity of the neck disability index and neck pain and disability scale for measuring disability associated with chronic, non-traumatic neck pain. Manual Therapy. 2009; 14(4):433-8. [DOI:10.1016/j. math.2008.07.005] [PMID]

[29] Hudak PL, Amadio PC, Bombardier C, Beaton D, Cole D, Davis A, et al. Development of an upper extremity outcome measure: The DASH (disabilities of the arm, shoulder, and head). American Journal of Industrial Medicine. 1996; 29(6):602-8. [DOI:10.1002/(SICI)10970274(199606)29:63.0.CO;2-L]

[30] Tate RL, McDonald S, Perdices M, Togher L, Schultz R, Savage S. Rating the methodological quality of single-subject designs and n-of-1 trials: Introducing the Single-Case Experimental Design (SCED) scale. Neuropsychological Rehabilitation. 2008; 18(4):385-401. [DOI:10.1080/09602010802009201] [PMID]

[31] Maher CG, Sherrington C, Herbert RD, Moseley AM, Elkins M. Reliability of the PEDro scale for rating quality of randomized controlled trials. Physical Therapy. 2003; 83(8):713-21. [DOI:10.1093/ptj/83.8.713] [PMID]

[32] Ezzati K, Sarrafzadeh J, Ebrahimi Takamjani I, Khani S. The efficacy of superficial and deep dry needling techniques on functional parameters in subjects with upper trapezius myofascial pain syndrome. Caspian Journal of Neurological Sciences. 2018; 4(4):152-8. [DOI:10.29252/cjns.4.15.152]

[33] Liu L, Huang Q-M, Liu Q-G, Thitham N, Li L-H, Ma Y-T, et al. Evidence for dry needling in the management of myofascial trigger points associated with low back pain: A systematic review and meta-analysis. Archives of Physical Medicine and Rehabilitation. 2018; 99(1):144-52.e2. [DOI:10.1016/j. apmr.2017.06.008] [PMID] 